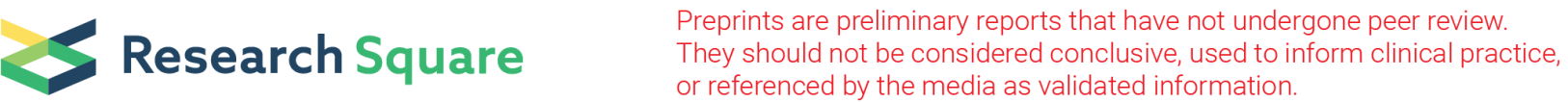

\section{Development of polyclonal antisera against movement proteins of the three poleroviruses infecting cucurbits and their serological relationships}

\section{Shao-kang Zhang}

China Agricultural University

Tian-yu Zhao

China Agricultural University

\section{Xing Shi}

China Agricultural University

Yu-zi Liu

China Agricultural University

\section{Ying Wang}

China Agricultural University

\section{Zong-ying Zhang}

China Agricultural University

\section{Da-Wei Li}

China Agricultural University

\section{Jia-lin Yu}

China Agricultural University

Chenggui Han ( $\sim$ hanchenggui@cau.edu.cn )

China Agricultural University

\section{Research}

Keywords: Cucurbit aphid-borne yellows virus, Melon aphid-borne yellows virus, Suakwa aphid-borne yellows virus, movement protein, prokaryotic expression, antiserum preparation, virus detection

Posted Date: January 16th, 2020

DOI: https://doi.org/10.21203/rs.2.21013/v1

License: (9) This work is licensed under a Creative Commons Attribution 4.0 International License. Read Full License 


\section{Abstract}

Background: Cucurbit aphid-borne yellows virus (CABYV), Melon aphid-borne yellows virus (MABYV) and Suakwa aphid-borne yellows virus (SABYV) are three critical viruses infecting cucurbit crops. The preparation of specific antiserum against the virus is crucial for both the detection of virus and understanding the functions of the related genes. However, there is no report about detecting the three viruses using antisera against movement proteins (MP).

Methods: In this study, we constructed prokaryotic expression vectors of the three viral movement proteins and transferred them into Escherichia coli strain Rosetta to purify the fusion proteins. Then the polyclonal antisera were obtained by immunizing New Zealand white rabbits. Western blotting was used to demonstrate the applicability of the three antisera.

Results: We discovered that the titer of antiserum against MP CABYV reached to 1:512000, and the titers of antisera against MP MABYV and MP SABYV reached to 1:256000. The optimized working concentration range for the three antisera was from 1:10000 to 1:64000. Both antisera against MP CABYV and MP MABYV could only react with the corresponding MP. The antiserum against MP SABYV not only had the strongest reaction with its MP but also could react with MP CABYV and MP MABYV at relative weaker levels and all the three antisera had no serological reactions with other poleroviruses tested. Furthermore, our results showed that the three antisera could specifically detect movement proteins both in Nicotiana benthamiana and cucumber leaves.

Conclusions: We have established a sensitive system for detecting three poleroviruses infecting cucurbits by antisera against movement proteins, providing a material foundation for the future research on both the serological detection of viruses and the interaction mechanisms between the virus and host plants.

\section{Background}

Cucurbitaceae is one of the most important fruits and vegetable crops in the world. Various plant viruses infecting cucurbits cause significant economic losses, which has become a limiting factor for the production of cucurbits [1-3]. Cucurbit aphid-borne yellows virus (CABYV), Melon aphid-borne yellows virus, (MABYV) and Suakwa aphid-borne yellows virus (SABYV) are important viruses infecting cucurbits, belonging to the genus polerovirus, the family Luteoviridae [4-6]. CABYV was first reported to infect cucurbit crops in France in 1992 and later found in many other countrie including China [4, 7-14]. Interestingly, CABYV can also infect passion fruit and pepper naturally, which causes a large area of yellowing symptoms in fields [15-17]. MABYV and SABYV were first reported in China in 2008 and 2009, respectively $[5,6]$. MABYV is widely distributed in many provinces in China and Thailand; however, SABYV has been only detected in coastal provinces such as Fujian and Guangdong in southern China $[2,6]$. Subsequently, SABYV was reported in Southeast Asian countries such as Thailand, the Philippines, and East Timor [18-20]. All the three viruses are limited to the phloem tissues of the host plant and are transmitted by aphids in a persistent circulative and non-proliferative manner. They are highly specific in 
vectors and cannot be transmitted mechanically [21]. Symptoms such as yellowing and thickening of old leaves could cause severe yield reductions. However, all three viruses have no significant effect on the quality and shape of fruits [4-7].

The virion of polerovirus including CABYV, MABYV and SABYV is a ball-shaped icosahedron with diameters of 25-30 nm, which encapsulate genome RNA. The virions are relatively stable and are not sensitive to chloroform and non-ionic detergents, but can be destroyed under high salt conditions with long time [22]. The genome consists of a single positive-stranded RNA approximately $5.7 \mathrm{~kb}$ in length, containing seven open reading frames (ORFs). The first three ORFs of them are expressed by genomic RNA and the others are expressed by subgenomic RNA [23].Specifically, the P0 protein encoded by ORF0 is a classic RNA silencing suppressor, which can enhance the pathogenicity of viruses and can promote the accumulation of virus through interacted with host plants genes [24-29]. The P1 protein encoded by ORF1 serves as protease, helicase, and VPg. A P1-P2 fusion protein is encoded through frameshift and has a replicase activity [22]. The intergenic-non-coding region (intergenic-NCR) approximately $80 \mathrm{nt}$ in length locates between ORF2 and ORF3a. The P3a protein without AUG initiation encoded by ORF3a is indispensable for the long-distance movement of the virus [30-31]. The coat protein is encoded by ORF3, participating in the packaging, long-distance movement, and aphids transmission of the virus [32]. ORF4 encodes MP through leaky scanning, which could locate in plasmodesmata, mitochondria, and chloroplast to regulate much infection process including replication, cell to cell movement, and longdistance movement [33-34]. The read-through protein encoded by ORF5 is closely related to aphids transmission, virion assembly, long-distance movement, and phloem limited and so on [35-38].

Serological methods, as one of the essential methods for virus detection, are widely used due to its simple preparation, strong specificity, and high sensitivity. In the current research, RT-PCR is mainly used for the detection of CABYV, MABYV, and SABYV $[18,39]$. In regards to the serological detection, only antiserum against CABYV prepared by purified virion was once used in Western blotting or ELISA [4]. Some recent studies showed that polyclonal antiserum against MP can detect the accumulation of virus from the family Luteoviridae [40-43]. However, there are no reports on either preparing polyclonal antiserum against MP of the three viruses or the serological relationships among them. In our work, in order to obtain polyclonal antisera, we used His-MBP-MP purified fusion protein by prokaryotic expression system to immunize New Zealand rabbits. Western blotting showed that all the three viruses were detected by these antisera specifically. We confirm the serological relationship among them and provide materials for future research on both the serological detection of viruses and the interactions between the virus and host plants.

\section{Results}

\section{Prokaryotic expression and purification of MP fusion proteins and development of antisera}


MPCABYV,$M P M A B Y V$ and MPSABYV genes were constructed into the pDB-His-MBP vector, which was transformed into Escherichia coli strain Rosetta to be expressed and purified. Then SDS-PAGE indicated that all the three recombinant proteins showed specific bands corresponding to $65 \mathrm{KDa}$, which is as predicted. Based on the results of SDS-PAGE, the purification is successful. His-MBP-CABYV-MP specific fusion protein was eluted at concentrations of 200 and $500 \mathrm{mM}$ imidazole (Fig. 1A), His-MBP-MABYV-MP specific fusion protein was eluted at concentrations of 100 and $200 \mathrm{mM}$ imidazole (Fig. 1B) and HisMBP-SABYV-MP specific fusion protein was eluted at concentrations of 80, 100 and $200 \mathrm{mM}$ imidazole (Fig. 1C), respectively. We sent $3 \mathrm{mg}$ of the concentrated proteins respectively to Beijing Protein Innovation Co.Ltd. (BPI) to immunize New Zealand white rabbits and approximately $30 \mathrm{~mL}$ of each polyclonal antiserum was successfully obtained.

\section{Titer analysis of the three antisera}

We constructed MP ${ }^{C A B Y V}, M^{M A B Y V}$, and MPSABYV into the pMDC32 vector to express target proteins. Then we transiently expressed all the three MPs in N. benthamiana via agro-infiltration and the pMDC32 empty vector served as the negative control. Leaves were collected at three dpi to extract total proteins for western blotting, which showed that all the antisera could detect the corresponding MP respectively. Furthermore, antiserum against MPCABYV still could detect the specific band when the antiserum was diluted to 512000 times (Fig. 2A). However, both antiserum against MPMABYV and antiserum against MPABYV can detect the specific bands when these two antisera were diluted to 256000 times (Fig. $2 \mathrm{~B}$ and $2 C)$. In summary, the titer of antiserum against MPCABYV reached to 1:512000 and both the titers of the other two antisera reach to 1:256000. From the perspective of color appearance and economics, the optimal working concentration range of the three antisera was from 1: 10000 to 1: 64000.

\section{Sensitivity analysis of the three antisera}

To analyze the sensitivity of the three antisera, N. benthamiana leaves expressing MPCABYV, MPMABYV , and MPSABV; the total proteins were extracted and diluted in equal proportion. Western blotting showed that the antiserum against MPCABYV diluted at 1:1000 could detect sample diluted to 128 times. Similarly, sample diluted to 64 times could be detected by the antiserum against MPMABYV and sample diluted to 40 times could be detected by the antiserum against MPSABYV used at the same ratio. Furthermore, samples diluted to 80 times, 16 times, and 32 times could be detected by the antisera against MPCABYV, MPMABYV, and MPSABYV diluted at 1:10000 respectively. When we diluted antisera at 1:20000, antiserum against $M^{C A B Y V}$ showed a higher sensitivity and samples diluted to 64 times still could be detected. However, under the same conditions, the other two antisera showed a lower sensitivity and samples diluted to 8 times could be detected (Fig. 3).

\section{Specificity analysis of the three antisera}


To analyze the specificity of the three antisera, we transiently expressed various MPs including MPCABYV $M^{M A B Y V}, P^{S A B Y V}$, 3Flag-MP ${ }^{\text {BrYV }}$ (Brassica yellow virus), 3Flag-MPPLRV (Potato leafroll virus) and 3FlagMPScYLV (Sugarcane yellow leaf virus) in N. benthamiana via agro-infiltration. The pMDC32 empty vector served as a negative control. Leaves were collected at $3 \mathrm{dpi}$ to extract total proteins for western blotting. The antisera were diluted at 1:1000, 1:10000 and 1:20000 respectively. Both antisera against MPCABYV and MPMABYV could only detect the corresponding MP no matter how antisera were diluted, showing a high specificity (Fig. 4A and 4B). Interestingly, although antiserum against MPSABV had the strongest reaction with MPSABYV at various dilution concentrations, MPCABYV and MPMABYV were still detected at weaker levels. This means that antiserum against MPSABYV could detect three different poleroviruses infecting cucurbits specifically (Fig. 4C). Furthermore, all the three antisera had no serological crossreactivity with other MPs from the same genus, including MPPLRV $\mathrm{MP}^{\mathrm{BrYV}}$ and MPScYLV.

\section{Application of the antisera in the virus detection}

We inoculated CABYV and MABYV infectious clones into N. benthamiana via agro-infiltration. Then we collected inoculated leaves at 3 dpi to extract total protein for western blotting. Detection results showed that both antisera specifically detected the CABYV and MABYV in N. benthamiana leaves, which is corresponding to the RT-PCR detection results (Fig. 5A and 5B). The results showed that our antisera were suitable for the detection of viruses in $\mathrm{N}$. benthamiana, the most widely used model plant in plant virology.

To test whether the antisera can detect MP in the natural host such as cucumber infected with a virus, we simulated the situations in which cucumber was infected with the virus, by mixing the diluted total protein-containing transient expressed MPs in N. benthamiana leaves with the extract of healthy cucumber leaves. Western blotting showed that protein samples diluted to 256 times, 64 times and 128 times could be specifically detected by the antisera against MPCABYV, MPMABYV and MPSABYV , respectively (Fig. 5C). Total protein from healthy cucumber leaves had no serological reaction with the three antisera and no interference with the specific serological responses of the three antisera to their corresponding MP protein.

\section{Discussion}

To some extent, the successful infection of the virus depends on the efficient movement in hosts. Blocking the movement of viruses provides strategies for host plants to resist viruses. Therefore, it is important to study how MP participates in the movement of the virus in hosts. MP plays an essential role in virus infection, which not only promotes the intercellular movement and systemic movement of the virus but also serves as a critical pathogenic factor to cause purple symptoms in the infected leaves [44]. Thus, we establish a specific detection system by developed antisera against three different MPs, which is indispensable to study the occurrence and distribution of viruses and the function of MP. 
Among the three developed antisera, antisera against MPCABYV and MPMABYV have shown higher specificities as they specifically reacted with their targeted proteins, whereas antiserum against MPSABYV could react with all three viruses in serology at the same time. Interestingly, we can distinguish three different viruses by the strength of the serological response, and the strongest response was MPSABYV, followed by MPMABYV and the weakest response was MP ${ }^{C A B Y V}$. MP ${ }^{C A B Y V}{ }_{\square M P} M^{M A B Y V}$ and MPSABYV share higher homology amongst them. At the nucleotide level, MPSABYV shares $79.7 \%$ identity with MPCABYV and $88.5 \%$ identity with MPMABYV . At the amino acid level, MPSABYV only shares $65.4 \%$ identity with MPCABYV and $75.1 \%$ identity with MPMABYV , which is positively correlated with the strength of the serological response.

Cucurbit crops such as cucumber, watermelon, melon, and pumpkin are the natural hosts of CABYV, MABYV and SABYV. The antisera we have developed are not only available for MP detection in the model plant $\mathrm{N}$. benthamiana, but also suitable in natural hosts. The simulating detection suggested that total protein from cucumber did not interfere with the specific reaction between antisera and MPs. Meanwhile, CABYV could be detected in the natural host passion fruit by the developed antiserum against MPCABYV, which provides new evidence for the application of the antiserum in fields [17]. Our work showed that the three antisera have a wide range of applications, although the detection on cucurbits needs further verification.

The antiserum developed based on the MP of Barley yellow dwarf virus (BYDV)-PAV Qinghai isolate not only reacted with PAV105 isolate sharing 79.3\% identity in amino acid, but also had strong serological cross-reactivity with the other BYDV MPs sharing $62.7 \%-83.3 \%$ identity in amino acid [43]. Among poleroviruses, Luffa aphid-borne yellows virus (LABYV), Pepo aphid-borne yellows virus (PABYV), and Cucumber aphid-borne yellows virus (CuABYV) also infect cucurbit crops [45]. In 2019, Zucchini aphidborne yellows virus (ZABYV) was reported as a new virus species in China [46]. The MPs of these viruses have $23.08 \%-75.92 \%$ identity with the MPs of CABYV, MABYV, and SABYV in amino acid (Table 1). PABYV MP showed the highest homology, and LABYV MP showed the lowest homology among them. However, further experiments are indispensable to investigate the serological relationship between MPs of these viruses and the three antisera we developed. 
Table 1

Comparison of amino acid sequence identities (\%) of movement protein between CABYV, MABYV, SABYV and other poleroviruses infecting cucurbits

\begin{tabular}{|lllll|}
\hline Poleroviruses & Accession Number & CABYV & MABYV & SABYV \\
\hline LABYV & NC_027703 & 24.27 & 26.83 & 23.08 \\
PABYV & NC_030225 & 75.92 & $70 . .31$ & 71.88 \\
CuABYV & FJ460218 & 59.28 & 59.28 & 60.31 \\
ZABYV & MK050791 & 56.48 & 55.44 & 55.96 \\
\hline
\end{tabular}

\section{Conclusions}

Diseases caused by CABYV, MABYV and SABYV are important viral diseases in the cucurbit crops. Development of specific antiserum is essential for virus detection and understanding the functions of the related genes. In our study, we purified three MPs by the prokaryotic expression system and developed polyclonal antisera with high titer, sensitivity, and specificity, although antiserum against MPSABYV had a relatively weaker reaction with $\mathrm{MP}^{\mathrm{CABYV}}$ and $M \mathrm{PPABYV}^{\mathrm{M}}$, which can be successfully used for virus detection and exploring the mechanisms of viral replication, movement and interaction with host plants.

\section{Materials And Methods}

\section{Plant materials and grown conditions}

The seeds of Nicotiana benthamiana were kindly donated by Professor David Baulcombe (Department of Plant Sciences, University of Cambridge, U.K), which were propagated and preserved in this laboratory. Nicotiana benthamiana was grown at the conditions of $24 \pm 1^{\circ} \mathrm{C}, 16 / 8$ hours light / dark cycle and forty percent humidity.

\section{The construction of vectors}

The full-length of MPCABYV,$M P^{M A B Y V}$, and MPSABYV were amplified by PCR using forward and reverse primers (Table 2). The PCR products were recycled by $1.0 \%$ agarose gel electrophoresis and linked into the vector pDB.His.MBP (DNASU Plasmid Repository, Arizona, USA) digested with restriction enzymes Ndel and $\mathrm{Xhol}$ at $37^{\circ} \mathrm{C}$ for more than 4 hours. We transformed the ligation products into E.coli strain MC1022 to obtain the positive clones and extracted plasmids. Sequencing analysis verified the

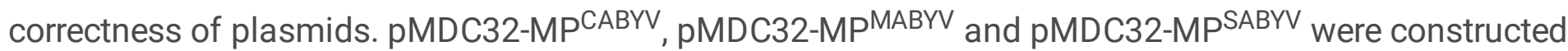
using the same methods [47]. 
Table 2

Specific primers used for vector construction

\begin{tabular}{|c|c|c|}
\hline Vector Name & Primer Name & primer sequence \\
\hline \multirow[t]{6}{*}{ PDB.His.MBP } & CABYVMPNdel & АACCTTTACTTCCAGGGCCATATGCAGGGAGGCGGAGGCGA \\
\hline & CABYVMPXhol & GGTGGTGGTGGTGCTCGAGTCCTATTTCGGGTTTTGGACC \\
\hline & MABYVMPNdel & AACCTTTACTTCCAGGGCCATATGGCATGGGAAGGAGGAGA \\
\hline & MABYVMPXhol & GGTGGTGGTGGTGCTCGAGTCTACCTATTTCGGGTTCTGG \\
\hline & SABYVMPNdel & AACCTTTACTTCCAGGGCCATATGGCATGGGAAGAAGGAGA \\
\hline & SABYVMPXhol & GGTGGTGGTGGTGCTCGAGTCTACCTATTTCGGGTTCTGG \\
\hline \multirow[t]{6}{*}{ pMDC32 } & CABYVMPKpnl & GGGGTACCATGCAGGGAGGCGGAGGCGA \\
\hline & CABYVMPSpel & GGACTAGTCCTATTTCGGGTTTTGGACC \\
\hline & MABYVMPKpnl & GGGGTACCATGGCATGGGAAGGAGGAGA \\
\hline & MABYVMPSpel & GGACTAGTCTACCTATTTCGGGTTCTGG \\
\hline & SABYVMPKpnl & GGGGTACCATGGCATGGGAAGAAGGAGA \\
\hline & SABYVMPSpel & GGACTAGTCTACCTATTTCGGGTTCTGG \\
\hline
\end{tabular}

\section{Agrobacterium-mediated transformation}

The liquid nitrogen freezing and thawing method were used to transform the transient expression vector plasmids into Agrobacterium. 3-5 $\mathrm{L}$ p plasmids were added into $100 \mu \mathrm{L}$ Agrobacterium competent cells GV3101, which was on the ice for 30 minutes and frozen in liquid nitrogen for 1 minute. Then it was melted at $37^{\circ} \mathrm{C}$ for $5 \mathrm{~min}$, and then $400 \mu \mathrm{L}$ LB liquid medium was added. After 4 hours of oscillation resuscitation at $28^{\circ} \mathrm{C}$, it was spread on the corresponding resistant LB plate. The transformed agrobacterium competent cells were grown at $28^{\circ} \mathrm{C}$ for $48 \mathrm{~h}$.

\section{The purification of recombinant proteins and the development of polyclonal antisera}

We transformed three prokaryotic expression vectors containing MP into E.coli strain Rosseta to obtain the positive colonies. Positive colonies were cultured in $10 \mathrm{ml}$ LB liquid medium containing kanamycin $(50 \mathrm{mg} / \mathrm{ml})$ and chloramphenicol $(34 \mathrm{mg} / \mathrm{ml})$ at $37{ }^{\circ} \mathrm{C}$ and $220 \mathrm{rpm}$ overnight for oscillating culture. All cultured bacteria were added to $1 \mathrm{~L}$ LB liquid medium containing kanamycin and chloramphenicol at $37^{\circ} \mathrm{C}$, and $220 \mathrm{rpm}$ for oscillating culture for $4-6 \mathrm{~h}$ in order to $O D_{600}$ ranged from $0.6 \sim 0.8$. Then the transformed bacteria were induced by shaking at $18^{\circ} \mathrm{C}$ and $180 \mathrm{rpm}$ for $18 \mathrm{~h}$ and Isopropyl- $\beta-\mathrm{D}$ thiogalactoside (IPTG; Sigma-Aldrich, St. Louis, MO, USA) was added at a final concentration of $0.1 \mathrm{mM}$. We collected the bacteria by centrifugation at $5000 \mathrm{rpm}$ for 6 minutes. After Ultrasonic crushing, we 
collected supernatant by centrifugation at $16000 \mathrm{rpm}$ for 40 minutes. The supernatant was added to a Niaffinity column (Qiagen, Hilden, Germany) and the proteins were eluted with imidazole eluent of different concentrations ( $20 \mathrm{mM}, 40 \mathrm{mM}, 60 \mathrm{mM}, 80 \mathrm{mM}, 100 \mathrm{mM}, 200 \mathrm{mM}$, and $500 \mathrm{mM})$. Each elution was subjected to SDS-PAGE for detecting whether MP was expressed and elution containing MP was concentrated to obtain purified fusion proteins.

The three fusion proteins then were immunized New Zealand white rabbits. When the immunization was completed, positive blood was taken from the carotid artery of New Zealand white rabbits, after centrifuged twice at $5000 \mathrm{rpm}$ for $10 \mathrm{~min}, 30 \mathrm{ml}$ of polyclonal antisera against MPCABYV , MPMABYV and MPSABYV were obtained respectively. (Beijing Protein Innovation Co.Ltd conducted the rabbit immunization).

\section{Western blotting assay}

Proteins were separated by SDS-PAGE and then transferred to the nitrocellulose membrane (GE Healthcare, Buckinghamshire, UK) by electrotransfer (200 mA, $100 \mathrm{~min})$. The NC membrane was blocked in $1 \times$ TBST buffer $(20 \mathrm{mM}$ Tris- $\mathrm{HCl}, 150 \mathrm{mM} \mathrm{NaCl}, 0.05 \%$ Tween-20, $\mathrm{pH}=8.0)$ containing $5 \%$ milk at $37^{\circ} \mathrm{C}$ for $1 \mathrm{~h}$, followed by incubated with polyclonal antisera against MPCABYV, MPMABYV and MPSABYV at $37^{\circ} \mathrm{C}$ for $1 \mathrm{~h}$. Subsequently, We washed the membrane with $1 \times$ TBST for three times and incubated the NC membrane with AP-labeled goat anti-rabbit IgG secondary antibody (Easybio, China) diluted to 1:20000 at $37^{\circ} \mathrm{C}$ for $1 \mathrm{~h}$. After washing the membrane with $1 \times$ TBST for three times, we incubated the NC membrane with the buffer containing NBT $\left(330 \mu \mathrm{g} \cdot \mathrm{mL}^{-1}\right)$ and BCIP $\left(165 \mu \mathrm{g} \cdot \mathrm{mL}^{-1}\right)$ to show corresponding bands.

\section{Titer determination of the three antisera}

pMDC32-MPCABYV, pMDC32-MPMABY and pMDC32-MPSABYV $\left(\mathrm{OD}_{600}=0.5\right)$ was co-expressed with P19 $\left(\mathrm{OD}_{600}=0.2\right)$ in $\mathrm{N}$. benthamiana, and the pMDC32 empty vector served as the negative control. Leaves were collected at three dpi for extracting total protein. All the three antisera were equally diluted followed by $1: 1000,1: 2000,1: 4000,1: 8000,1: 16000,1: 32000,1: 64000,1: 128000,1: 256000$ and 1:512000 in Western blotting experiments to determine its titer and optimal working concentration.

\section{Sensitivity analysis of the three antisera}

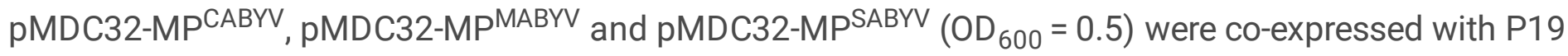
$\left(\mathrm{OD}_{600}=0.2\right)$ in $\mathrm{N}$. benthamiana and the pMDC32 empty vector served as the negative control. Leaves were collected at $3 \mathrm{dpi}$ for extracting total protein. We weighed $0.1 \mathrm{~g}$ of $\mathrm{N}$. benthamiana leaves and added $300 \mu \mathrm{L} 2$ XSDS buffer to prepare protein samples. The samples were diluted by two gradients $(1: 4,1: 8$, $1: 16,1: 32,1: 64,1: 128,1: 256,1: 512,1: 1024$ and 1:40, 1:80, 1:160, 1:320, 1:640) in Western blotting experiments. Meanwhile, all three antisera were diluted to 1:1000, 1:10000, and 1:20000 respectively.

\section{Specificity analysis of the three antisera}


$M^{C A B Y V}, M P^{M A B Y V}, M P^{S A B Y V}, 3 F l a g-M P^{B r Y V}, 3 F l a g-M P^{P L R V}$ and $3 F$ lag-MPScYLV $\left(O_{600}=0.5\right)$ was coexpressed with $\mathrm{P} 19\left(\mathrm{OD}_{600}=0.2\right)$ in $\mathrm{N}$. benthamiana, and the pMDC32 empty vector served as the negative control. Leaves were collected at $3 \mathrm{dpi}$ for extracting total protein. We performed western blotting to detect specificity of the antisera. The three antisera were all diluted at the ratio of 1:1000, $1: 10000$ and 1:20000 respectively.

Detection of $\mathrm{N}$. benthamiana inoculated with full-length infectious clones

We inoculated $\mathrm{N}$. benthamiana with the full-length infectious clone of CABYV and MABYV [48-49]. Transient expression vectors PMDC32-MPCABYV and pMDC32-MPMABYV served as the positive control and the pCass-RZ empty vector served as the negative control. Western blotting was performed using antisera at 1:10000, which was compared with the RT-PCR detection of the same sample.

\section{Simulation detection of natural host plants with infected virus}

Total proteins from $\mathrm{N}$. benthamiana leaves expressing MPCABYV , MPMABYV and MPSABYV were extracted followed by the same dilution ratio as healthy cucumber leaves (1:4). Then we mixed them with equal volume, which was equally diluted by $1: 16,1: 32,1: 64,1: 128,1: 256$ and 1:512. N. benthamiana leaves expressing the pMDC32 empty vector, and healthy cucumber leaves served as the negative controls. While N. benthamiana leaves expressing MPCABYV ${ }^{\text {MPMABYV }}$ and MPABYV served as the positive control respectively. Then we conducted Western blotting using antisera at 1:10000 to simulate the serological detection of CABYV, MABYV and SABYV in the natural host cucumber.

\section{Abbreviations}

BrYV: Brassica yellow virus; CABYV: Cucurbit aphid-borne yellows virus; CuABYV: Cucumber aphid-borne yellows virus; ELISA: Enzyme-linked Immunosorbent Assay; IPTG: Isopropyl- $\beta$-D- thiogalactoside; LABYV: Luffa aphid-borne yellows virus; MABYV: Melon aphid-borne yellows virus; MP: Movement Protein; ORF: Open Reading Frame; PABYV: Pepo aphid-borne yellows virus; PLRV: Potato leafroll virus; RT-PCR: Reverse transcription polymerase chain reaction; SABYV: Suakwa aphid-borne yellows virus; ScYLV: Sugarcane yellow leaf virus; SDS-PAGE: Sodium Dodecyl Sulphate Polyacrylamide Gel Electrophoresis; TBST: Tris-buffered saline; ZABYV; Zucchini aphid-borne yellows virus.

\section{Declarations}

\section{Acknowledgments}

We thank Professor Xian-Bing Wang and Dr. Yong-Liang Zhang, and other lab members for their constructive suggestions. We also thank Dr. Salah Bouzoubaa (University of Strasbourg, France) for providing E. coli strain MC1022 and thank Dengpan Zuo for providing the transient expression vectors 
including 3Flag-MP ${ }^{\mathrm{BrYV}}$, 3Flag-MPPLRV and 3Flag-MPScYLV. We are grateful to Nitesh Datt for the revision of the manuscript and Zhitong Zhang for the cultivation of Nicotiana benthamiana plants.

\section{Funding}

This work was supported by the National Natural Science Foundation of China (31671995 and 31000840)

\section{Competing interests}

The authors declare that they have no competing interests.

\section{Availability of data and material}

All data generated or analyzed during this study are included in this published article. Materials are available from the corresponding author on reasonable request.

\section{Authors' contributions}

CGH conceived the study and revised the manuscript critically. SKZ, XS and YZL designed and carried out the experiments. SKZ and TYZ drafted the manuscript. YW, ZYZ, DWL and JLY contributed reagents/materials/analysis tools. All authors read and approved the final manuscript.

\section{Ethics approval and consent to participate}

Not applicable

\section{Consent for publication}

All the participants are consent for publication.

\section{Author details}

${ }^{1}$ Ministry of Agriculture Key Laboratory of Pest Monitoring and Green Management, and State Key Laboratory for Agro-biotechnology, China Agricultural University, Beijing, 100193, P. R.China. ${ }^{2}$ Department of plant pathology, College of Plant Protection, China Agricultural University, Beijing, 100193, P. R.China. ${ }^{3}$ Department of Microbiology \& Immunology, College of Biological Sciences, China Agricultural University, Beijing, 100193, P. R.China.

\section{References}

1. Gholamalizadeh R, Vahdat A, Keshavarz T, Elahinia A, Bananej K. Occurrence and distribution of ten viruses infecting cucurbit plants in guilan province, Iran. Acta virol. 2008;52:113-8. 
2. Knierim D, Tsai W S, Maiss E, Kenyon L. Molecular diversity of poleroviruses infecting cucurbit crops in four countries reveals the presence of members of six distinct species. Arch Virol. 2014;159:145965.

3. Chikh-Ali M, Natsuaki T, Karasev A V. Molecular diversity of main cucurbit viruses in Syria. J Plant Pathol. 2019;101:1067-75.

4. Lecoq $H$, Bourdin D, Wipe-scheibel C. A new yellowing disease of cucurbits caused by a luteovirus, Cucurbit aphid-borne yellows virus. Plant Pathol. 1992;41:749-61.

5. Xiang HY, Shang QX, Han CG, Li DW, Yu JL. Complete sequence analysis reveals two distinct poleroviruses infecting cucurbits in China. Arch Virol. 2008a;153:1155-60.

6. Shang QX, Xiang HY, Han CG, Li DW, Yu JL. Distribution and molecular diversity of three cucurbitinfecting poleroviruses in China. Virus Res. 2009;145:341-6.

7. Lemaire O, Gubler W D, Valencia J, Lecoq H, Falk B W. First report of Cucurbit aphid-borne yellows virus in the United States. Plant Dis. 1993;77:1169.

8. Abou-Jawdah Y S H, Fayyad A. First report of cucurbit aphid-borne yellows luteovirus in Lebanon. Plant Dis. 1997;81:1.

9. Juarez M. First report of Cucurbit aphid-borne yellows virus in Spain. Plant Dis. 2004;88:907.

10. Mnari M. First report of Cucurbit aphid-borne yellows virus in Tunisia causing yellows on five cucurbitaceous species. Plant Dis. 2005;89:776.

11. Tomassoli L, Meneghini M. First report of Cucurbit aphid-borne yellows virus in Italy. Plant Pathol. 2007; $56: 720$.

12. Xiang HY, Shang QX, Han CG, Li DW, Yu JL. First report on the occurrence of Cucurbit aphid-borne yellows virus on nine cucurbitaceous species in China. Plant Pathol. 2008b;57:390.

13. Bananej K, Vahdat A, Predajna L, Glasa M. Molecular characterization of geographically different cucurbit aphid-borne yellows virus isolates. Acta Virol. 2009;53:61-4.

14. Orfanidou C, Maliogka V I, Katis N I. First Report of Cucurbit chlorotic yellows virus in Cucumber, Melon, and Watermelon in Greece. Plant Dis. 2014;98:1446-7.

15. Vidal A H, Sanches M M, Alves-Freitas D M T, Abreu E F M, Lacorte C, Pinheiro-Lima B, Rosa R C C, Jesus N, Campos M A, Varsani A, Ribeiro S G. First World Report of Cucurbit Aphid-Borne Yellows Virus Infecting Passionfruit. Plant Dis. 2018;102:2665.

16. Liu Y, Li F, Li YY, Zhang SB, Gao XW et al. Identification, Distribution and Occurrence of Viruses in the Main Vegetables of China. Scientia Agricultura Sinica. 2019;52:239-61. (In Chinese)

17. Zhang SK, Zhao TY, Liu JT, Zi LY, Li XY, Wang Y, Zhang ZY, Li DW, Yu JL, Han CG. First Report of Cucurbit Aphid-Borne Yellows Virus in Passion Fruit Plants Exhibiting Mosaic and Mottling in China. Plant Dis. 2019. https://doi.org/10.1094/PDIS-07-19-1378-PDN.

18. Knierim D, Deng T C, Tsai W S, Green S K, Kenyon L. Molecular identification of three distinct polerovirus species and a recombinant cucurbit aphid-borne yellows virus strain infecting cucurbit crops in Taiwan. Plant Pathol. 2010;59:991-1002. 
19. Maina S, Edwards O R, de A L, Ximenes A, Jones R A J. First Complete Genome Sequence of Suakwa aphid-borne yellows virus from East Timor. Genome Announc. 2016;4.pii:e00718-16.

20. Cheewachaiwit S, Warin N, Phuangrat B, Rukpratanporn S, Gajanandana O, Balatero C H, Chatchawankanphanich $\mathrm{O}$. Incidence and molecular diversity of poleroviruses infecting cucurbit crops and weed plants in Thailand. Arch Virol. 2017;162:2083-90.

21. Brault V, Uzest M, Monsion B, Jacquot E, Blanc S. Aphids as transport devices for plant viruses. C R Biol. 2010;333:524-38.

22. D`Arcy C, Domer L. Luteoviridae. Virus taxonomy, VIIlth report of the ICTV. In F CM, M MA, Maniloff J, D U, B L A. Elsevier/Academic Press, London, UK. 2005;pp:891-900.

23. Guilley H, Wipf-Scheibel C, Richards K, Lecoq H, Jonard G. Nucleotide sequence of cucurbit aphidborne yellows luteovirus. Virology. 1994;202:1012-17.

24. Prufer D, Kawchuk L M, Rohde W. Polerovirus ORF0 genes induce a host-specific response resembling viral infection. Can J Plant Pathol. 2006;28:302-9.

25. Han YH, Xiang HY, Wang Q, Li YY, Wu WQ, Han CG, Li DW, Yu JL. Ring structure amino acids affect the suppressor activity of melon aphid-borne yellows virus P0 protein. Virology. 2010;406:21-7.

26. Zhuo T, Li YY, Xiang HY, Wu ZY, Wang XB, Wang Y, Zhang YL, Li DW, Yu JL, Han CG. Amino acid sequence motifs essential for P0-mediated suppression of RNA silencing in an isolate of Potato leafroll virus from Inner Mongolia. Mol Plant Microbe Interact. 2014;27:515-27.

27. Sun Q, Li YY, Wang Y, Zhao HH, Zhao TY, Zhang ZY, Li DW, Yu JL, Wang XB, Zhang YL, Han CG. Brassica yellows virus $\mathrm{PO}$ protein impairs the antiviral activity of NbRAF2 in Nicotiana benthamiana. J Exp Bot. 2018;69:3127-39.

28. Li YY, Sun Q, Zhao TY, Xiang HY, Zhang XY, Wu ZY, Zhou CJ, Zhang X, Wang Y, Zhang YL, Wang XB, Li DW, Yu JL, Dinesh-Kumar SP, Han CG. Interaction between Brassica yellows virus silencing suppressor P0 and plant SKP1 facilitates stability of P0 in vivo against degradation by proteasome and autophagy pathways. New Phyto. 2019;222:1458-73.

29. Mamun O R, Zhang XY, Wang Y, Li DW, Yu JL, Han CG. The three essential motifs in PO for suppression of RNA silencing activity of Potato leafroll virus are required for virus systemic infection. Viruses. 2019;11:170.

30. Smirnova E, Firth A E, Miller W A, Scheidecker D, Brault V, Reinbold C, Rakotondrafara A M, Chung B Y W, Ziegler-Graff V. Discovery of a Small Non-AUG-Initiated ORF in Poleroviruses and Luteoviruses That Is Required for Long-Distance Movement. PLOS Pathog. 2015;11:e1004868.

31. Zhang XY, Zhao TY, Li YY, Xiang HY, Dong SW, Zhang ZY, Wang Y, Li DW, Yu JL, Han CG. The Conserved Proline18 in the Polerovirus P3a Is Important for Brassica Yellows Virus Systemic Infection. Front Microbiol. 2018;9:613

32. Ziegler-Graff V, Brault V, Mutterer J D, Simionis M T, Herrbach E, Guilley H, Richards K E, Jonard G. The coat protein of beet western yellows luteovirus is essential for systemic infection but the viral gene products P29 and P19 are dispensable for systemic infection and aphid transmission. Mol Plant Microbe Interact. 1996;9:501-10. 
33. Sokolova M, Prufer D, Tacke E, Rohde W. The potato leafroll virus $17 \mathrm{kDa}$ movement protein is phosphorylated by a membrane-associated protein kinase from potato with biochemical features of protein kinase C. FEBS Letters. 1997;400:201-5.

34. DeBlasio S L, Xu Y, Johnson R S, Rebelo A R, MacCoss M J, Gray S M, Heck M. The Interaction Dynamics of Two Potato Leafroll Virus Movement Proteins Affects Their Localization to the Outer Membranes of Mitochondria and Plastids. Viruses. 2018;10:585.

35. Brault V, Vandenheuvel J F J M, Verbeek M, Ziegler-Graff V, Reutenauer A, Herrbach E, Garaud J C, Guilley H, Richards K, Jonard G. Aphid transmission of beet western yellows luteovirus requires the minor capsid read-through protein P74. EMBO J. 1995;14:650-9.

36. Bruyère A, Brault V, Ziegler-Graff V, Simonis M T, Van J F J M, Richards K, Guilley H, Jonard G, Herrbach E. Effects of Mutations in the Beet Western Yellows Virus Readthrough Protein on Its Expression and Packaging and on Virus Accumulation, Symptoms, and Aphid Transmission. Virology. 1997;230:323-34.

37. Peter K A, Gildow F, Palukaitis P, Gray S M. The C Terminus of the Polerovirus P5 Readthrough Domain Limits Virus Infection to the Phloem. J Virol. 2009;83:5419-29.

38. Hipper C, Monsion B, Bortolamiol-Becet D, Ziegler-Graff V, Brault V. Formation of virions is strictly required for turnip yellows virus long-distance movement in plants. J Gen Virol. 2014;95(Pt2):496505.

39. Shang QX, Xiang HY, Li DW, Yu JL, Han CG. Rapid Detection and Differentiation of Three Cucurbitinfecting Poleroviruses by Multiplex RT-PCR. J Agric Sci. 2012;4:209-16.

40. Chay C A, Gunasinge U B, Dinesh-Kumar S P, Miller W A, Gray S M. Aphid transmission and systemic plant infection determinants of Barley yellow dwarf luteovirus-PAV are contained in the coat protein readthrough domain and 17-kDa protein, respectively. Virology. 1996;219:57-65.

41. Li N, Chen Z, Liu Y, Liu Y, Zhou XP, Wu JX. Development of monoclonal antibodies and serological assays specific for Barley yellow dwarf virus GAV strain. Virol j. 2015;12:136-44.

42. Yang F, Mamun OR, Zhang XY, Zhang ZY, Wang Y, Li DW, Yu JL, Han CG. Development of polyclonal antiserum against movement protein from potato leafroll virus and its application for the virus detection. Phytopathol Res. 2019;1:169-74.

43. Hu RJ, Zhao TY, Zuo DP, Wang Y, Zhang ZY, Han CG. Antiserum preparation of the movement protein of Barley yellow dwarf virus PAV Qinghai isolate and its serological relationships with other BYDVs. Acta Phytopathologica Sinica. 2019;1-6. (In Chinese)

44. Chen XR, Wang Y, Zhao HH, Zhang XY, Wang XB, Li DW, Yu JL, Han CG. Brassica yellows virus' movement protein upregulates anthocyanin accumulation, leading to the development of purple leaf symptoms on Arabidopsis thaliana. Sci Rep. 2018;8:16273.

45. Knierim D, Maiss E, Kenyon L, Winter S, Menzel W. First full-length genome sequence of the polerovirus luffa aphid-borne yellows virus (LABYV) reveals the presence of at least two consensus sequences in an isolate from Thailand. Arch Virol. 2015;160:2633-6. 
46. Peng B, Kang BS, Wu HJ, Liu LF, Liu LM, Fei ZJ, Hong N, Gu QS. Detection and genome characterization of a novel member of the genus polerovirus from zucchini (cucurbita pepo) in china. Arch Virol. 2019;164:2187-91.

47. Curtis M D, Grossniklaus U. A gateway cloning vector set for high-throughput functional analysis of genes in planta. Plant Physiol. 2003;133:462-9.

48. Prufer D, Wipf-Scheibel C, Richards K, Guilley H, Lecoq H, Jonard G. Synthesis of a full-length infectious cDNA clone of cucurbit aphid-borne yellows virus and its use in gene exchange experiments with structural proteins from other luteoviruses. Virology. 1995;214:150-8.

49. Xiang HY, Shang QX, Dong SW, Han CG, Li DW, Yu JL. Construction of infectious cDNA clone of Melon aphid yellow virus. Proceedings of the 2009 annual meeting of the Chinese society of plant pathology. 2009. (In Chinese)

\section{Figures}

A

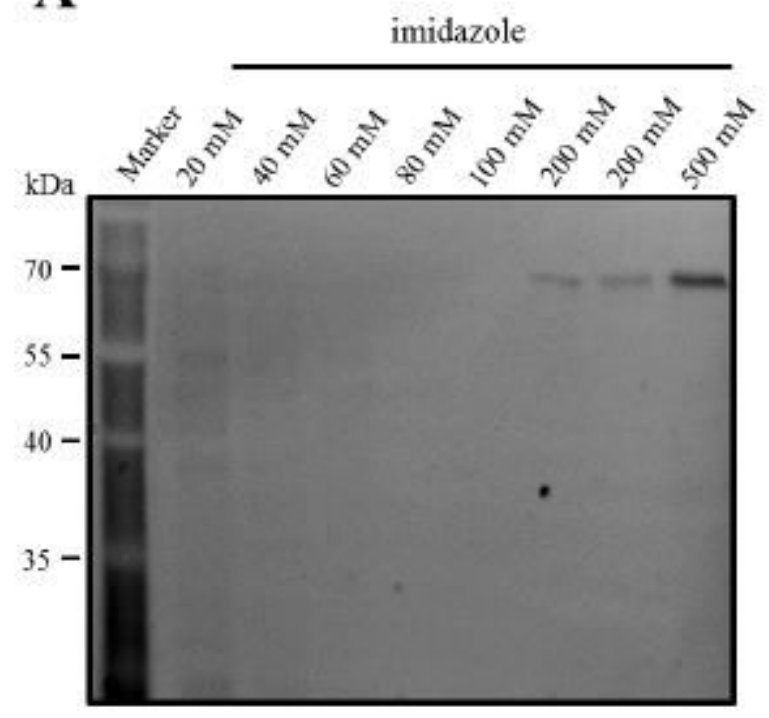

C

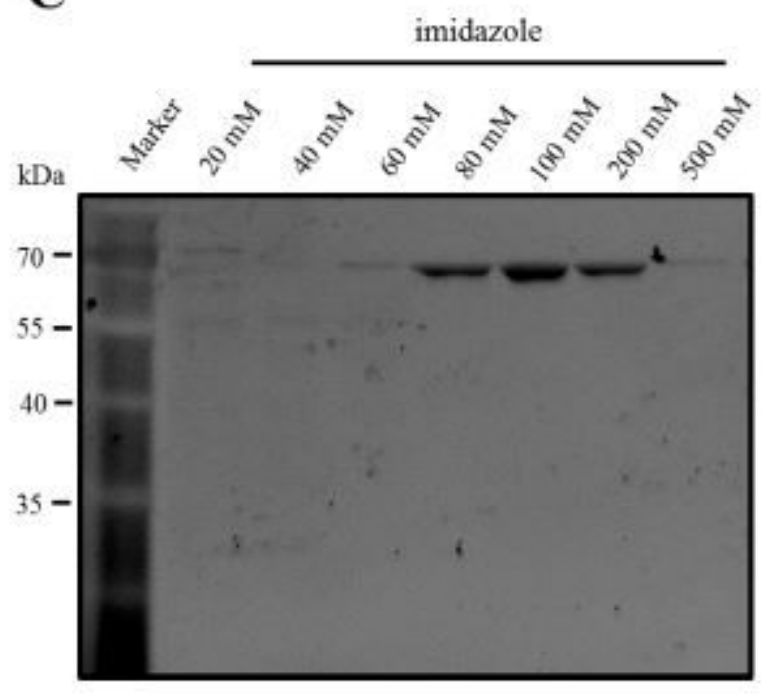

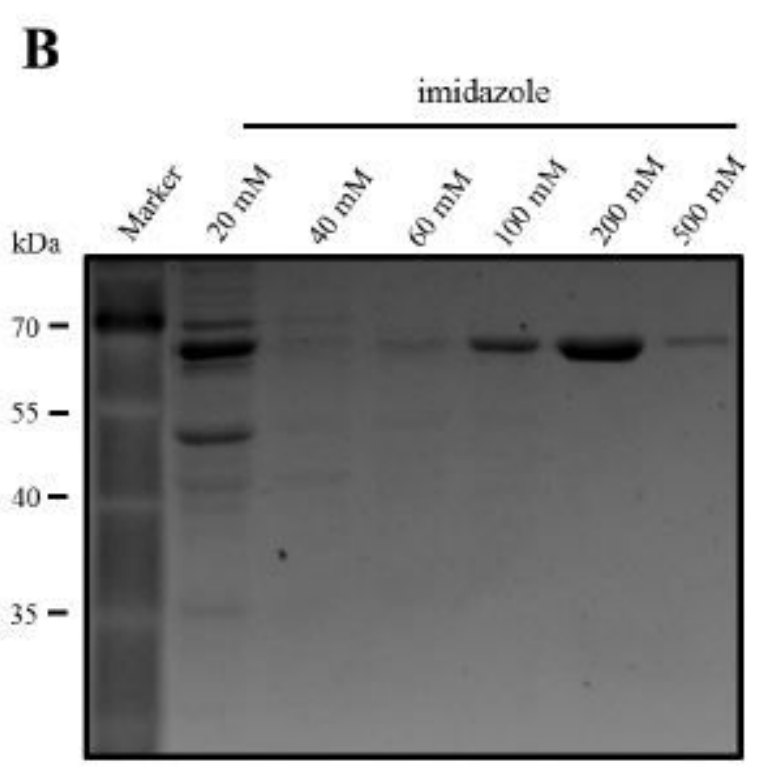




\section{Figure 1}

SDS-PAGE analysis of CABYV-MP(A), MABYV-MP(B) and SABYV-MP(C) recombinant proteins. The first lane was PageRuler Prestained Protein Ladder (Marker), and the other lanes were fusion proteins eluted with 7 different concentrations of imidazole respectively.

A

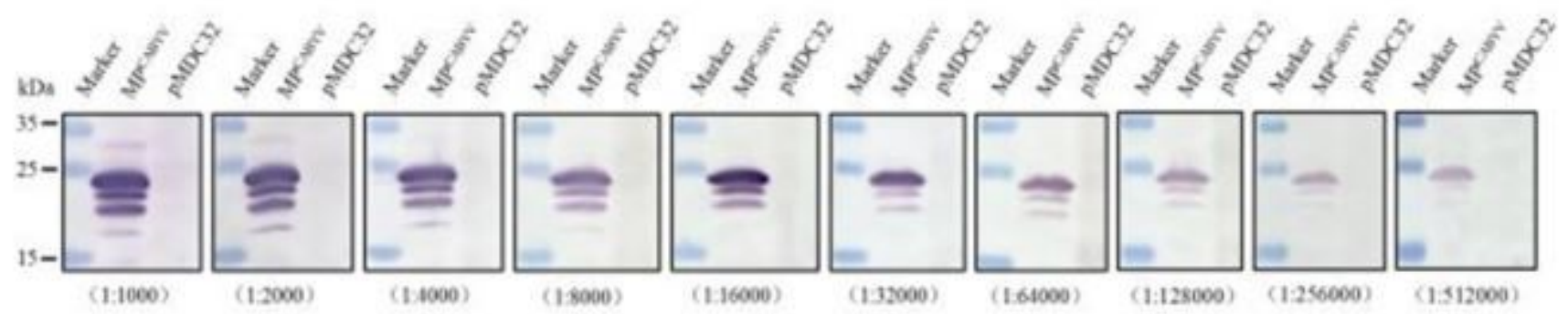

B

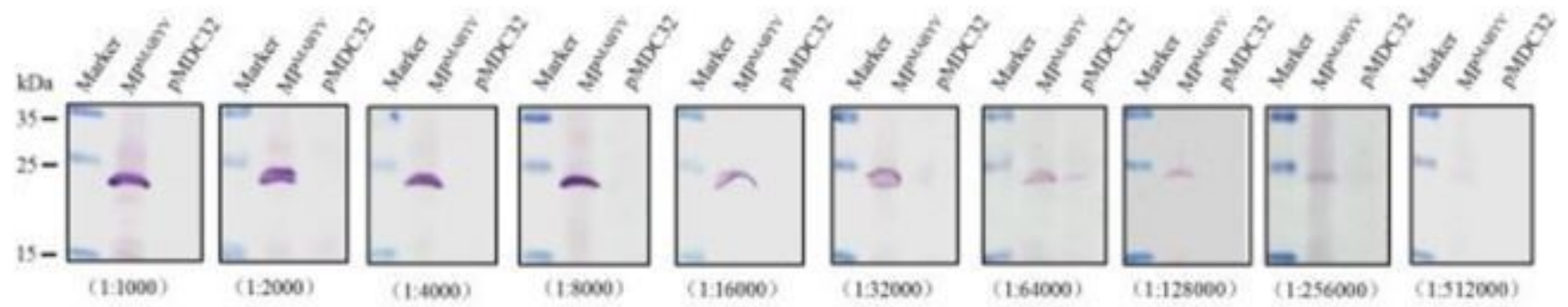

C

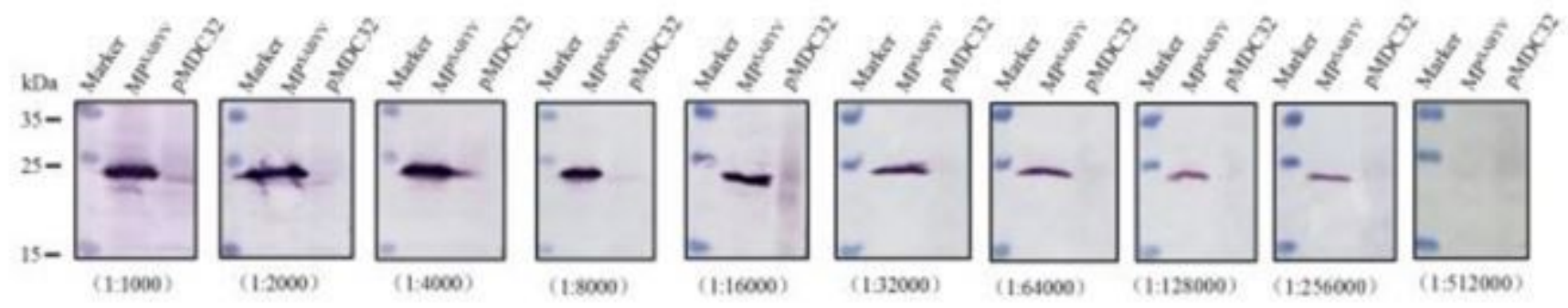

Figure 2

Titer determination of the three antisera by Western blotting (A\&B\&C). All the three antisera were used at 10 different dilutions (1:1000, 1:2000, 1:4000, 1:8000, 1:16000, 1:32000, 1:64000, 1:128000, 1:256000 and 1:512000). Each panel consisted of a left lane of PageRuler Prestained Protein Ladder (Marker), a middle lane containing total proteins extracted from $\mathrm{N}$. benthamiana leaves transiently expressed MPCABYV, MPMABYV and MPSABYV protein respectively. pMDC32 empty vector was used as a negative control in the right lane. 
A

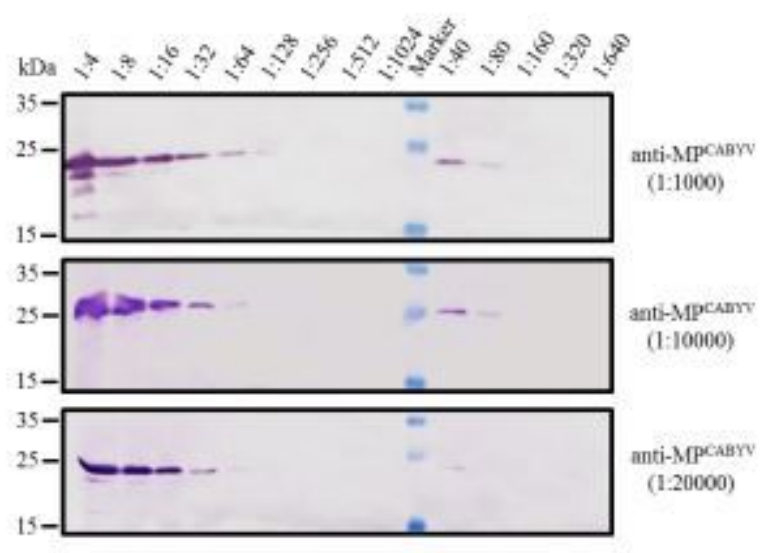

C

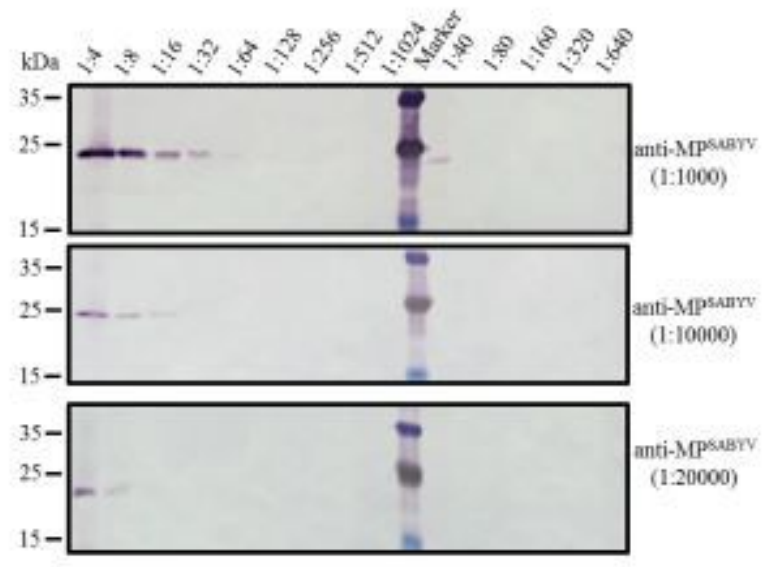

B

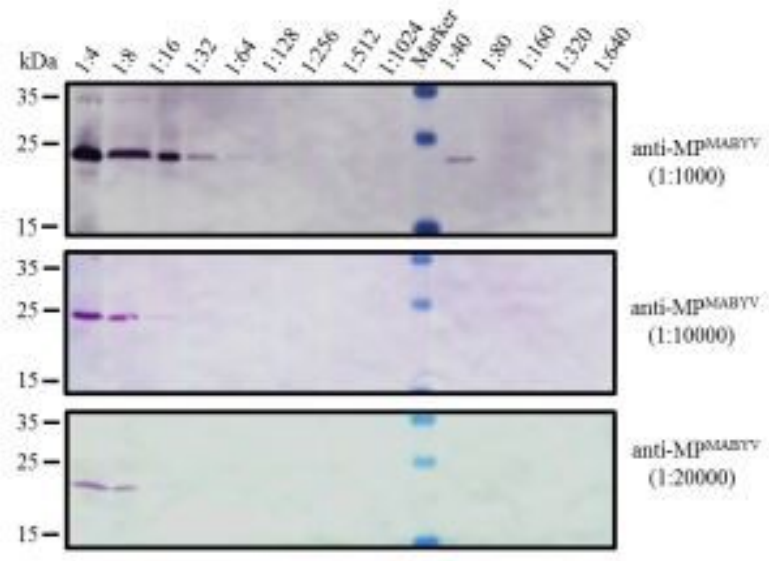

\section{Figure 3}

Sensitivity analysis of the three antisera by Western blotting. Lane Marker: meaned PageRuler Prestained Protein Ladder, and the rest of the lanes showed two different dilutions of protein samples extracted from N. benthamiana leaves $(1: 4,1: 8,1: 16,1: 32,1: 64,1: 128,1: 256,1: 512,1: 1024$ and 1:40, 1:80, 1:160, 1:320, 1:640). Anti-MPCABYV (A), anti-MPMABYV (B) and anti-MPSABYV (C) were used the ratio of 1:1000, 1:10000 and 1:20000, respectively.

A

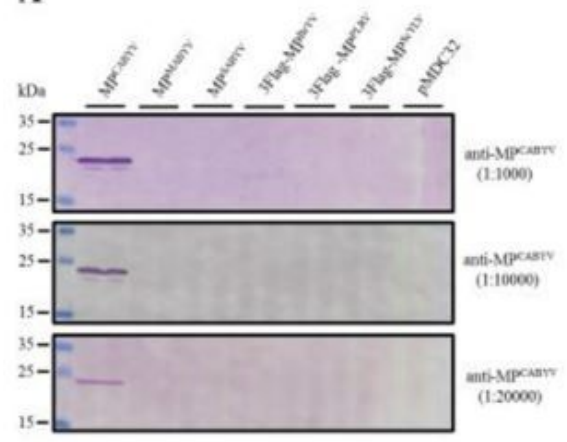

B

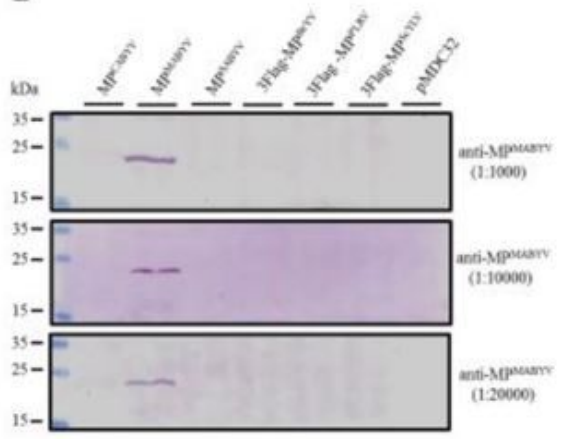

C

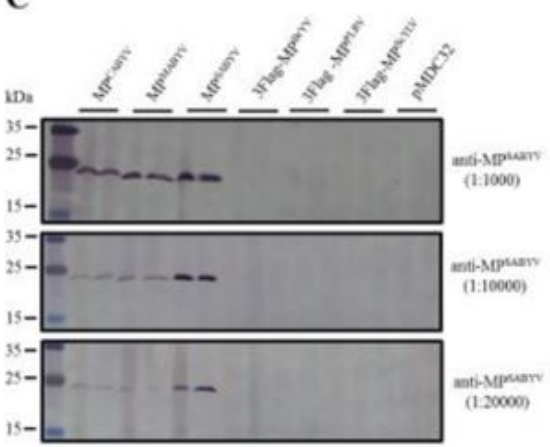


Specificity analysis of the three antisera by Western blotting. The leftmost lane was PageRuler Prestained Protein Ladder (Marker), and the rest of lanes were proteins extracted from $\mathrm{N}$. benthamiana leaves transient expressing different MPs including CABYV, MABYV, SABYV, BrYV, PLRV and ScYLV. pMDC32 empty vector was used as a negative control. The three antisera were used at the ratio of 1:1000, 1:10000 and 1:20000 respectively.

\section{A}
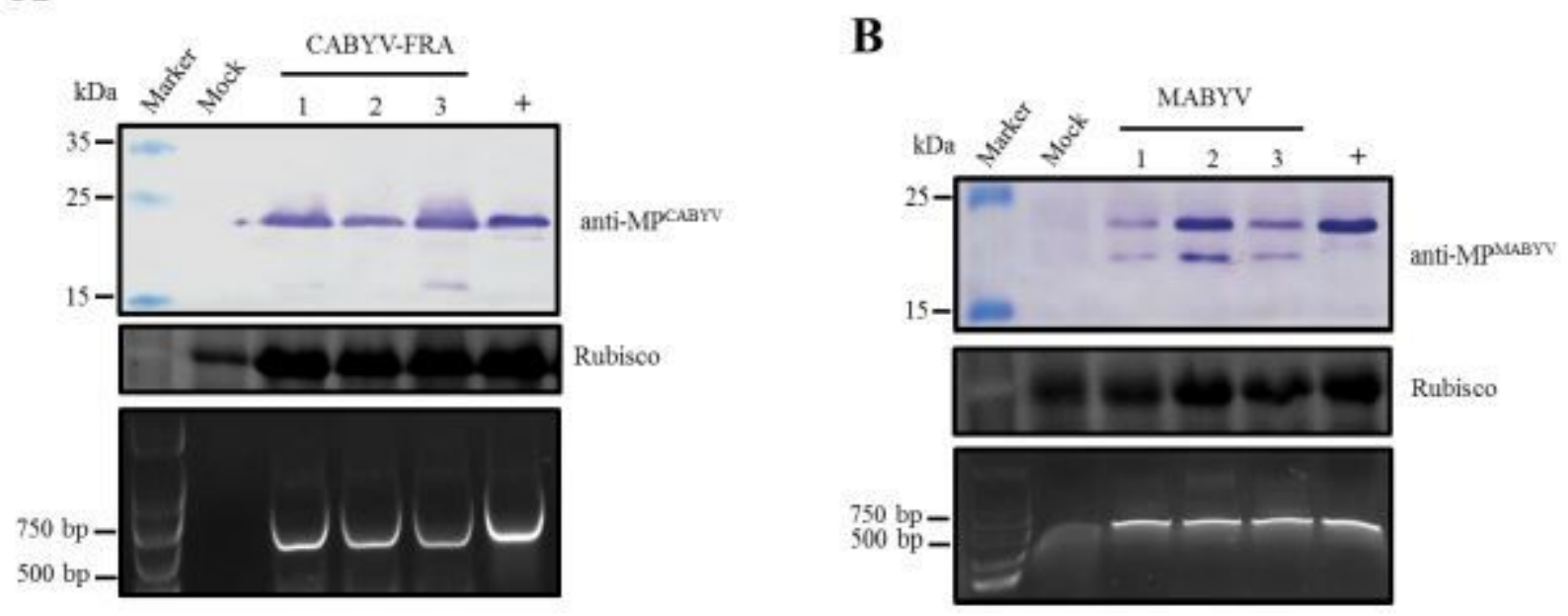

\section{C}

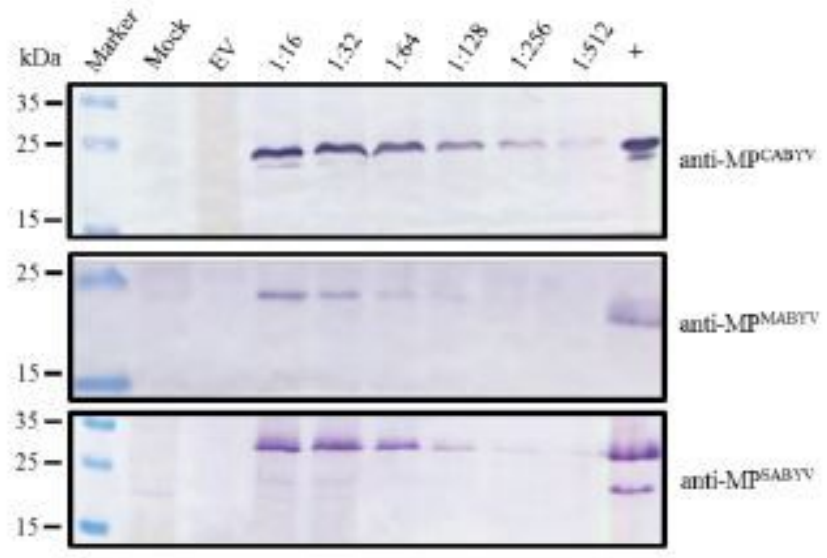

\section{Figure 5}

Applicability analysis of the three antisera by Western blotting. (A and B) Comparison of detections of CABYV and MABYV from $N$. benthamiana leaves inoculated with full-length infectious clone using corresponding antiserum and RT-PCR. Lane Marker: PageRuler Prestained Protein Ladder. Lane Mock: inoculated pCass-RZ empty vector. Lane 1, 2, 3: three separate protein samples expressing CABYV or MABYV infectious clone. Lane "+": protein extracted from N. benthamiana leaves transiently expressed MPCABYV and MPMABYV. Rubisco stained with Coomassie brilliant blue was used as a loading control (Middle panel). The lower panel was RT-PCR detection from the same samples. (C) Simulation detection of Cucumber infected with CABYV, MABYV and SABYV. Lane Marker: PageRuler Prestained Protein Ladder. Lane Mock: protein extract from healthy cucumber leaves. Lane EV: N. benthamiana leaves inoculated pMDC32 empty vector. Lane "+": protein extracted from N. benthamiana leaves transiently 
expressing the three MP genes. The rest of the lanes showed multiple dilutions mixed with cucumber protein and N. benthamiana protein (1:16, 1:32, 1:64, 1:128, 1:256 and 1:512). The three antisera were used at the ratio of 1:10000 respectively. 